\title{
GENERATION OF OPTIMIZED PREPARATIONS OF BONE MORPHOGENETIC PROTEINS FOR BONE REGENERATION
}

\author{
Kh. V. MALYSHEVA, ${ }^{1,2}$ I. M. SPASYUK ${ }^{3}$, O. K. PAVLENKO ${ }^{3}$, \\ R. S. STOIKA ${ }^{1}$, O. G. KORCHYNSKYI ${ }^{1,4}$ \\ ${ }^{1}$ Institute of Cell Biology, National Academy of Sciences of Ukraine, Lviv; \\ ${ }^{2}$ Insitute of Animal Biology, National Academy of Agrarian Sciences of Ukraine, Lviv; \\ ${ }^{3}$ Ivan Franko National University of Lviv, Ukraine; \\ ${ }^{4}$ Centre for Innovative Research in Medical and Natural Sciences, \\ Medical Faculty of Rzeszow University, Poland; \\ e-mail: olexkor@hotmail.com
}

\begin{abstract}
Correction of inherited skeletal abnormalities, traumas affecting wide bone areas and non-healing fractures require efficient bone formation and regeneration. Bone morphogenetic proteins (BMPS) are signaling molecules that play a crucial role in bone and cartilage formation and regeneration. Osteoinductive properties of existing hydroxyapatite-based osteoplastic materials are frequently insufficient for efficient bone regeneration, thus raising a requirement for novel matrices involving BMPs for highly efficient local induction of bone formation at the area of the bone defect. The aim of this study was conducting in vitro optimization of osteoinductive properties of recombinant BMPs preparations to be used in bone regenerative practice. Recombinant BMPs were produced in human embryonic kidney 293 cells upon their transfection or co-transfection with plasmids expressing BMP2 and BMP7 at different ratios. A quality of BMP preps was validated based on their ability to induce in vitro osteoblast differentiation of C2C12 cells. Alkaline phosphatase that is widely used as a marker of osteoblast differentiation was measured spectrophotometrically. We found that the most effective inducer of osteoblast differentiation was recombinant BMP preparation produced upon cotransfection of $85 \%$ of BMP2 and 15\% of BMP7 plasmids, that is most likely due to generation of conditions most favorable for formation of BMP2/7 heterodimers. Frozen BMP2/7 preparations stored for $3 \mathrm{~h}$ in experimental setup and for several weeks in routine work do not lose their osteoinductive properties compared with freshly prepared BMP2/7 preparations and can be successfully used for generation of highly efficient bone regenerative matrices.
\end{abstract}

Key words: bone morphogenetic proteins, bone regeneration, osteogenesis, mouse mesenchymal stem cells, alkaline phosphatase.

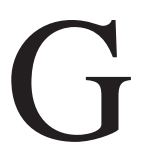
enetic diseases, non-jointing fractures and other traumas (including military) often lead to large bone defects. Therefore, efficient high-quality bone grafting is critically important in the healing of bone defects that occur as their result. In addition, $10 \%$ of hip replacement operations (primarily - osteoporosis patients) have failed due osteolysis at the site of prosthesis integration. Apart of that, it is often necessary to increase the bone density and thickness in the patient's jaw to be sufficient for an effective dental implant integration and maxillofacial surgery. On the other hand, the bone morphogenetic proteins (BMPs) are inducers of bone formation during embryogenesis, and they are essential for maintenance of the skeletal homeostasis
[1]. Thus, usage of osteoplastic materials incuding BMPs for local induction of bone formation in the area of the bone defect is highly promising.

The history of BMPs study began in the middle of 1960s with the observation that demineralized bone matrix is able to induce ectopic bone formation in subcutaneous and intramuscular pockets in rodents [2, 3]. However, it was not possible until the late 1980s, when the first BMPs were characterized and cloned, that individual BMPs could be studied biochemically [4]. Many studies have since demonstrated the ability of BMPs to induce endochondral/ intramembranous ossification and chondrogenesis, by inducing mesenchymal stem cells differentiation towards the osteoblastic lineage, being critical 
for maintenance of the skeletal integrity and in bone fracture healing. BMPs are synthesized by osteoprogenitor cells, osteoblasts, chondrocytes and platelets but their production is not restricted to bone, since they also play an essential role in development and cell functions in other organs $[4,5]$.

BMPs belong to a group of multifunctional signaling molecules that belong to the transforming growth factor- $\beta$ (TGF- $\beta$ ) superfamily of proteins. BMPs synthesized as precursor proteins with an $\mathrm{N}$-terminal signal peptide, a pro-domain for folding and secretion, and a C-terminal mature peptide. Precursors are formed in the cytoplasm as dimeric proprotein complexes, which are cleaved by pro-protein convertases to generate $\mathrm{N}$ - and $\mathrm{C}$-terminal fragments. The C-terminal mature fragment is capable of binding to its receptor, with the non-covalently associated pro-domain playing an important regulatory role $[4,6]$.

BMPs can perform signaling functions through both canonical and non-canonical pathways. In the canonical signaling pathway, they initiate the signal transduction cascade by binding to cell surface receptors and forming a heterotetrameric complex comprised of two dimers of type I and type II serine/ threonine kinase receptors [7]. Both receptor types have a short extracellular domain, a single transmembrane domain, and an intracellular domain with serine/threonine kinase activity. There are seven type I receptors (ALK1-7) for the TGF- $\beta$ family of ligands, four of which bind BMPs: type $1 \mathrm{~A}$ BMP receptor (BMPR-1A or ALK3), type 1B BMP receptor (BMPR-1B or ALK6), type 1A activin receptor (ActR-1A or ALK2) and ALK1 receptor, which binds BMP9. There are four type II receptors for the TGF- $\beta$ family, three of which can interact with BMPs: type 2 BMP receptor (BMPR-2), type 2A activin receptor (ActR-2A), and type $2 \mathrm{~B}$ activin receptor (ActR-2B). While BMPR-1A, BMPR-1B, and BMPR-2 are specific to BMPs, ActR-1A, ActR-2A, and ActR-2B can function as receptors for activins, which are also members of the TGF- $\beta$ superfamily. The mechanism of the heterotetrameric signaling complex formation can vary. The existence of preformed oligomeric complexes adds an additional layer of intricacy; indeed, binding to preformed receptor complexes versus BMP-induced receptor recruitment can activate different pathways $[4,8,9]$.

Upon formation of a heterotetrameric complex, the constitutively active type II receptor trans-phosphorylates the type I receptor at a glycine-serine rich motif known as the GS domain. This activates the type I receptor and allows phosphorylation of the immediately downstream substrate proteins known as the receptor-regulated Smads (R-Smads) at a C-terminal SSXS motif. The R-Smads involved in BMP signaling are Smad1, Smad5, and Smad8 (Smad1/5/8). R-Smads then associate with the comediator Smad (co-Smad) Smad4, and this complex translocates to the nucleus where it functions as a transcription factor with coactivators and corepressors to regulate gene expression. Inhibitory Smads (I-Smads), Smad6 and Smad7 (Smad6/7), are involved in feedback inhibition of the signaling pathway $[4,10,11]$.

Interestingly, BMPs heterodimers containing subunits of various groups (e.g. BMP2/7 or BMP4/6) more effectively activate BMP signaling pathways and, as a result, exhibit higher osteoinductive properties [12].

BMPs are crucial growth factors regulating numerous processes of skeletal formation, hematopoiesis, neurogenesis, as well as defining the differentiation map of cells during embryonic development [13].

More than fifty years after the discovery by Marshal R. Urist at least 20 human BMPs were identified and they possess varying degrees of the inductive activity. Two of these, BMP2 and BMP7, have become the subject of extensive research aimed at developing therapeutic strategies for the restoration and treatment of skeletal conditions [14, 15]. Thus, a main goal of this study was generation of optimized recombinant BMPs preparations that can be used in bone regenerative practice.

\section{Materials and Methods}

Reagents and ligands. Plasmids expressing BMP2 and BMP7 full-length cDNA were purchased from Open Biosystems/GE Healthcare (Lafayette, CO, USA). pShuttle-CMV vector was kindly provided by Dr. Bert Vogelstein. Human recombinant BMP2 and BMP7 were purchased from PeproTech (Rocky Hill, NJ, USA). Heterodimeric human recombinant BMP2/7 was purchased from R\&D Systems (Minneapolis, MN, USA).

Cloning strategy. Full-length human BMP2 cDNA was digested with EcoRI and NotI enzymes in an order to re-clone it from non-expressing MGC (Mammalian Gene Collection) vector pINCY into highly efficient mammalian expressing vector $\mathrm{pDEF}$ [16]. Human BMP2-DEF and BMP7-pSport6.1 con- 
structs were digested with KpnI and NotI enzymes in order to reclone full-length cDNAs into pShuttleCMV expression plasmids that confer kanamycin resistance gene.

Cell culture. Our studies were performed using immortalized mouse mesenchymal precursor cells of C2C12 line, human embryonic kidney 293 (HEK293) cells and human mesenchymal stem cells (hMSC) were isolated from bone marrow aspirate of the surgical material obtained upon hip replacement surgery under informed patient's consent. A pluripotency of hMSC was evaluated based on their capacity to efficiently differentiate into osteoblast, adipocyte and chondrocyte lineages upon proper stimulation and conditions. C2C12 and HEK293 cells were cultured in Dulbecco's modified Eagle's medium (DMEM, Biowest, France) containing 10\% fetal bovine serum (FBS, Biowest, France). hMSC were cultured in low-glucose (1 mg/ml) DMEM supplemented with $10 \mathrm{ng} / \mathrm{ml}$ of basic fibroblast growth factor. All cells were grown in a $5 \% \mathrm{CO}_{2}$-containing atmosphere at $37^{\circ} \mathrm{C}$ and $100 \%$ humidity. Culture medium was refreshed every 2-3 days. Before subcultivation cells were washed with phosphate-buffered saline (PBS) that contained $137 \mathrm{mM} \mathrm{NaCl}, 2.7 \mathrm{mM} \mathrm{KCl}, 4.3 \mathrm{mM}$ $\mathrm{Na}_{2} \mathrm{HPO}_{4}$ and $1.4 \mathrm{mM} \mathrm{KH}_{2} \mathrm{PO}_{4}$ with $\mathrm{pH}$ 7.4.

Transfection of HEK293 cells. HEK293 were seeded at $60-70 \%$ of confluency in 6 or $9 \mathrm{~cm}$ Petri dishes "Anumbra". Next day, cells were transfected with plasmid constructs expressing BMP2 and BMP7 and control plasmid - pcDNA3 (correspondingly 5 or $20 \mu \mathrm{g} / \mathrm{ml}$ of total DNA per dish). Transfection was carried out using transfection reagent polyethylenimine (PEI, Polysciences Inc., Warrington, PA, USA) following the manufacturer's protocol. After transfection (4-7 h), culture medium was replaced with a fresh complete medium. After $48 \mathrm{~h}$ of transfection, we collected conditioned medium, which contained BMP2 and BMP7 homo- or heterodimers. Depending on the type of experiment, the conditioned medium was stored at $4{ }^{\circ} \mathrm{C}$ in refrigerator (Samsung, Seoul, Korea) or at $-70^{\circ} \mathrm{C}$ in ultra low temperature freezer (NuAire, Plymouth, MN, USA) in sample holders. Due to the absence of alive cells in these preparations no cryoprotectors or special cryoconservation programs were employed.

Luciferase reporter assays. hMSC cells were split at a density of $1.10^{4}$ cells per $\mathrm{cm}^{2}$ in 12-well plates. The following day, cells were transiently transfected with a BMP-specific luciferase reporter adenovirus we generated before at a multiplicity of infection, MOI of 190) in a combination with $\beta-G a l$ construct $(\mathrm{MOI}=10)$ to be used as an internal control for the efficacy of transduction. Six $h$ later a culture medium was refreshed. After $36 \mathrm{~h}$ of transfection, cells were starved for $12 \mathrm{~h}$ in a $0.1 \%$ FCSDME, re-fed with the fresh $0.1 \%$ FCS-DME and treated with indicated ligands for the next 12-15 h. $\beta$-Galactosidase activity was quantified in $100 \mathrm{mM}$ $\mathrm{Na}_{2} \mathrm{HPO}_{4} / \mathrm{NaH}_{2} \mathrm{PO}_{4}, 1 \mathrm{mM} \mathrm{MgCl}, 100 \mathrm{mM}$ 2-mercaptoethanol, and $0.67 \mathrm{mg} / \mathrm{ml}$ O-nitrophenylgalactopyranoside spectrophotometrically. Both luciferase reporter and $\beta$-galactosidase activity assays were conducted using luciferase reporter assay reagent (Promega, Madison, WI, USA) on a Victor 3 machine (Perkin Elmer, Waltham, MA, USA) [16]. Each transduction was carried out in triplicate and repeated at least twice.

Induction of osteoblast differentiation. Cells of $\mathrm{C} 2 \mathrm{C} 12$ line can be induced to differentiate into osteoblasts by different BMPs, including BMP2 and BMP7. Cells were split at a density of $1.5 \cdot 10^{4}$ cells per $\mathrm{cm}^{2}$ in 12- or 24-well plates, respectively. Next day, cells were treated with fresh differentiation-supporting medium supplemented with $50 \mathrm{mg} / \mathrm{ml}$ ascorbic acid complete culture medium in a $1: 1$ ratio with conditioned medium, which contained BMP2 and BMP7 in appropriate proportions. In a current study, we addressed the evaluation of early osteoblast differentiation, therefore other components, like $\beta$-glycerophospate that is required as a source of calcium for matrix mineralization, were not necessary. On the third day after induction, C2C12 cells were repetitively treated with conditioned medium. During osteogenesis assay, C2C12 cells were cultured for 4 days.

Alkaline phosphatase assay. The alkaline phosphatase activity produced by $\mathrm{C} 2 \mathrm{C} 12$ was analyzed spectrophotometrically using a $\pi$-nitrophenylphosphate ( $\pi$-NPP), as a substrate [17]. Four days after induction of osteogenesis, the cells were washed twice with $0.4 \mathrm{ml}$ of $1 \mathrm{X}$ PBS per well. Afterwards, cells were lysed in $0.2 \mathrm{ml}$ of alkaline phosphatase (ALP) lysis buffer $(10 \mathrm{mM}$ glycine, $100 \mu \mathrm{M} \mathrm{MgCl}, 10 \mu \mathrm{M} \mathrm{ZnCl}_{2}, 0.1 \%$ Triton X-100) per well and agitated gently for $5 \mathrm{~min}$. Then, $10 \mu \mathrm{l}$ aliquot of cell lysate was placed into a 96-well plate and ALP activity was revealed with $90 \mu \mathrm{l} /$ well of ALP assay buffer $\left(100 \mathrm{mM}\right.$ glycine, $1 \mathrm{mM} \mathrm{MgCl}{ }_{2}$, $100 \mu \mathrm{M} \mathrm{ZnCl}$ ) supplemented with $6 \mathrm{mM} \pi$-NPP (Pierce-Thermo Fisher Scientific, Grand Island, NY, USA) [18]. Plates were agitated gently and incubated 
at room temperature until color developed. The absorption was measured at $405 \mathrm{~nm}$ in a 96-well plate reader (BioTek, Winooski, VT, USA). The level of expression of the enzyme is directly proportional to the intensity of mesenchymal stem cells osteogenic differentiation [17].

All experiments were repeated twice using three parallel wells in each variant. Results of spectrophotometric measurements of ALP activity are expressed as mean \pm standard deviation. Data were analyzed using GraphPad Prism 6 program. Statistical differences between experimental variants were assessed by Student's t-test. Appropriate $P$ values were shown in graphs to demonstrate the significance of the results. Only differences with $P$-values lower than 0.05 were regarded as significant.

\section{Results and Discussion}

The heterodimers consisting of subunits that belong to different groups of BMPs (e.g. BMP2/7 or BMP4/6) activate BMP signaling pathway more effectively and, as a result, exhibit higher osteoinductive properties due to recruiting subunits belonging to different BMP type I receptor subclasses [12]. We carried out a comparative study of the osteoinductive properties of the recombinant BMP2, BMP6, and
BMP2/7 heterodimers. As osteoinductive properties of different BMPs directly depend on the intensity of BMP signaling pathway activation, we used in our work luciferase reporter assays that allow quantifying the level of activation BMP-Smad signaling pathway in a wide linear range.

As shown in Fig. 1, the activation of the BMP signaling pathway in hMSC using $50 \mathrm{ng} / \mathrm{ml}$ of BMP6/6 was observed. Twice higher activation of the BMP-sensitive BRE-Luc reporter system than activation in cells treated with BMP2/2 at the same concentration was found. For such activation of BMP signaling pathway, we used BMP7/7 at three-fold higher concentration (data not shown here). Probably, this recombinant protein was partially inactivated because of its interaction with secreted protein product of its target gene Noggin. The mechanism of such effect was established recently [18]. At the same time, BMP2/7 heterodimers at a concentration of $10 \mathrm{ng} / \mathrm{ml}$ show comparable effect with BMP6/6 at five-fold higher concentration.

A search for recombinant BMPs preparations with the best osteoinductive properties. The main goal of our work was to choose the optimal combinations of recombinant BMPs preparations demonstrating the best osteoinductive effect. Thus,

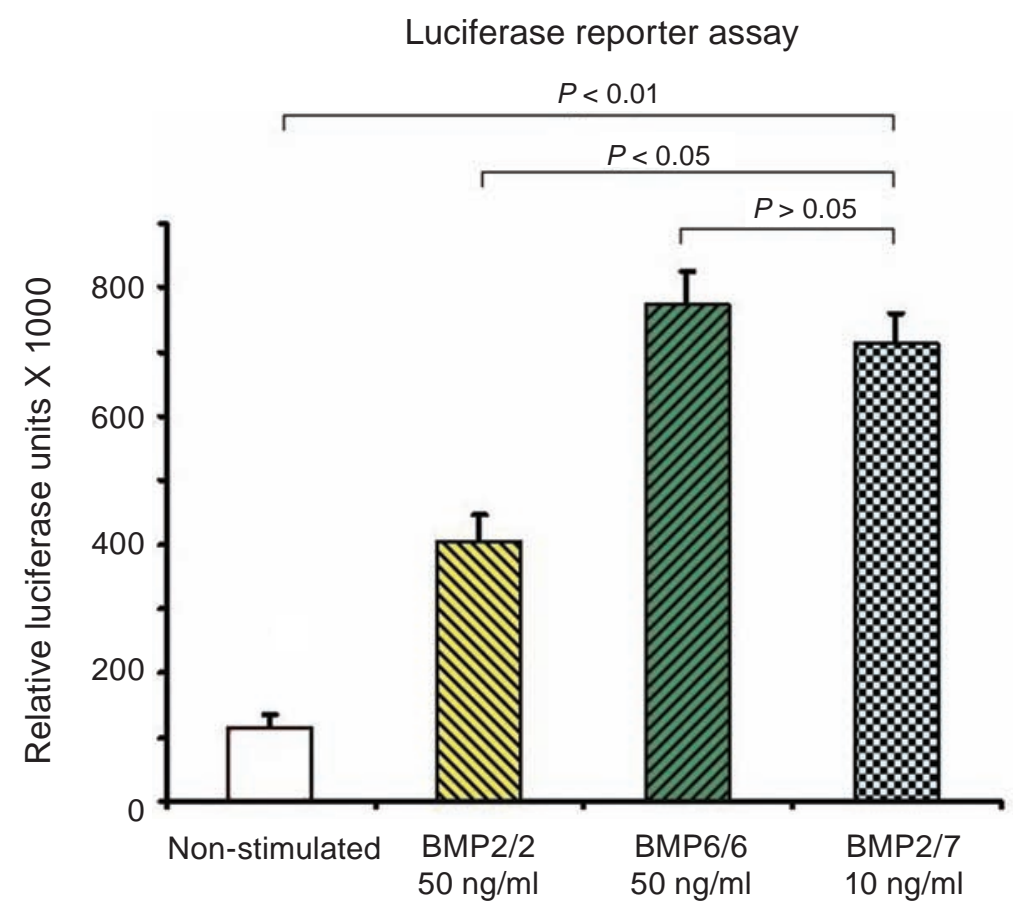

Fig. 1. The BMP2/7 heterodimers at a concentration of $10 \mathrm{ng} / \mathrm{ml}$ are more potent activators of BMP signaling pathway than BMP2/2 and equally potent with BMP6/6 homodimers at a concentration of $50 \mathrm{ng} / \mathrm{ml} \mathrm{each}$. Luciferase reporter assay was carried out with human mesenchymal stem cells 
we carried out a study of the combination of BMP2 and BMP7 action in different proportions. For this, we used a commonly accepted model of cell line HEK293, which is widely used for various research purposes due to its high efficiency, in particular, for the production of recombinant proteins (in our case BMPs).

HEK293 cells were transfected with plasmid constructs expressing BMP2 and BMP7 and control plasmid - pcDNA3, that does not contain the coding sequence of the genes which products can affect the results of the experiment. The transfection (or cotransfection) with indicated plasmids was carried out in the following proportions (Table 1).

To validate the efficacy of combined action of BMP2 and BMP7 in a comparison with a separate use of each ligand we re-cloned both cDNAs into a similar vector pShuttle that confers a kanamycin resistance. After $48 \mathrm{~h}$ of transfection of HEK 293 cells, we collected conditioned medium (CM) containing secreted BMP2 and BMP7 homo- or heterodimers in appropriate proportions. We mixed this CM in a $1: 1$ ratio with fresh culture medium. On the same day, the induction of C2C12 was carried out. Two days after induction re-addition of CM was performed as one-time stimulation resulted in low induction of $\mathrm{C} 2 \mathrm{C} 12$ osteoblast differentiation. Analysis of the experiment results was performed by spectrophotometric measurement of ALP activity, which is widely used as a marker of osteoblast differentiation (Fig. 2). As one can see from Fig. 2, both BMP2/2 and BMP7/7 expressed from this vector had a relatively low osteoinductive activity: respectively 2.5 and 2.4 times higher than a control vehicle. Mixture of these constructs in equimolar concentrations was 1.8 times more effective. While taking into account a low osteoinductive activity of these preparation, we generated the optimized version of BMP2 expression plasmid upon its re-cloning into pDEF vector that confers a high expression level for recombinant proteins [16] and used in a parallel with a BMP7 subcloned into a pSport6.1 vector. Figure 3 shows the results of the comparison between recombinant plasmids based on different vectors used in the study. As it is clear from such comparison made side-byside into one experiment, optimized versions of vectors (hBMP2-pDEF in a combination with hBMP7pSport6.1) in a case of optimal ratio between BMP2 and BMP7 was almost three times more efficient that original variant (pShuttle-CMV vector). Most efficient combination appeared to be $75 \%$ BMP2/25\% BMP7.
Table 1. The proportions of plasmids expressing $B M P 2$ and BMP7 (crude evaluation)

\begin{tabular}{|l|c|c|c|c|c|}
\hline BMP2, \% & 100 & 75 & 50 & 25 & 0 \\
\hline BMP7, \% & 0 & 25 & 50 & 75 & 100 \\
\hline
\end{tabular}

The next experiment was carried out for more accurate determination of recombinant BMP2 and BMP7 concentrations in the preparation, which showed the best osteoinductive effect in the preceding study.

This experiment was carried out similarly to the previous one. The HEK293 cells transfection (or co-transfection) with plasmid constructs expressing BMP2 and BMP7 was performed in the following proportions (Table 2).

The CM that already contained recombinant BMP2/7 in appropriate proportions was collected $48 \mathrm{~h}$ after transfection. On the same day, the induction of $\mathrm{C} 2 \mathrm{C} 12$ osteoblast differentiation was carried out similarly to previous experiment Analysis of the experimental results was performed by a spectrophotometric measurement of the ALP activity (Fig. 3).

It was shown that BMPs preparation produced upon co-transfection of $85 \%$ of BMP2 and 15\% of BMP7 is the most effective inducer of $\mathrm{C} 2 \mathrm{C} 12$ osteoblast differentiation.

The study of recombinant BMP preparations osteoinductive properties after their storage at low temperature. It is well known that freezing-thawing can lead to the destruction of proteins, particularly their complexes. Therefore in our next experiment we studied the possibility of maintaining the osteoinductive properties of recombinant BMPs during their short-term low-temperature storage.

This experiment was carried out similarly to the previous studies. We collected the CM (48 h after transfection), which included recombinant BMP2/7 in ratios that were described in Table 1 . One part of $\mathrm{CM}$ aliquots we stored at $4{ }^{\circ} \mathrm{C}$ for $3 \mathrm{~h}$, and the other part - at $-70{ }^{\circ} \mathrm{C}$ during the same period of time.

On the same day, the fresh culture medium was mixed in a $1: 1$ ratio with $\mathrm{CM}$ and the induction of $\mathrm{C} 2 \mathrm{C} 12$ cells was carried out in two versions: $\mathrm{A}-\mathrm{CM}$ after short-term storage at $4{ }^{\circ} \mathrm{C}, \mathrm{B}-\mathrm{CM}$ after shortterm storage at $-70{ }^{\circ} \mathrm{C}$.

Two days after osteoblast differentiation induction, CM re-addition was performed in an appropriate way. The results of spectrophotometric measurement of ALP activity are presented in Fig. 4. 


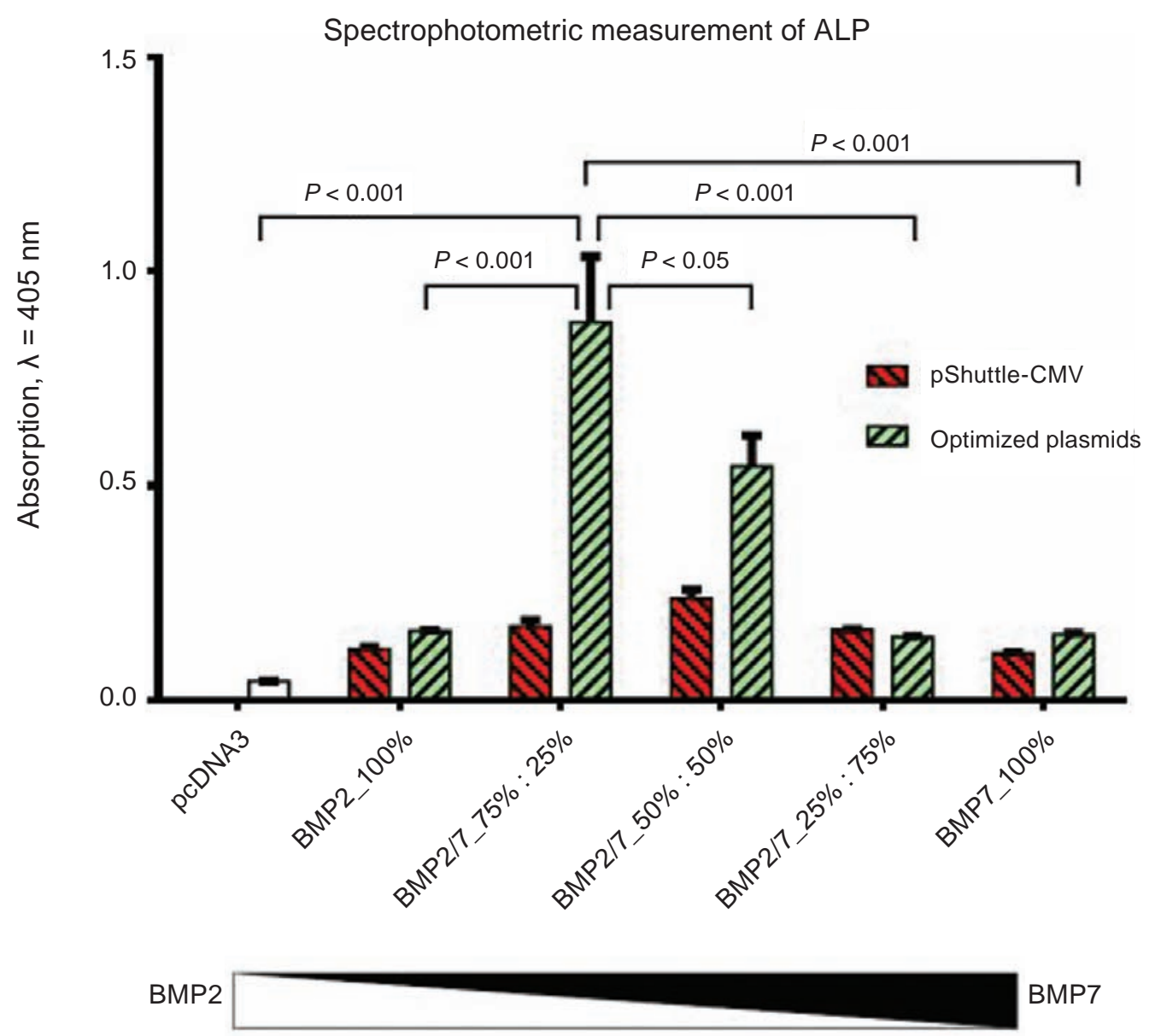

Fig. 2. The BMPs preparation generated upon transfection of $75 \%$ of BMP2 and $25 \%$ of BMP7 plasmids into producer HEK293 cells was the most effective inducer of osteoblast differentiation in C2C12 mesenchymal cells (crude evaluation). Producer cells of HEK293 line were transfected with plasmids expressing BMP2 and BMP7 at indicated ratios. Two days after transfection, the CM with secreted BMPs was collected, and mixed with fresh culture medium. The osteogenic properties of BMP preparations were tested using mesenchymal C2C12 cells. The intensity of osteogenesis was evaluated spectrophotometricaly by measuring the ALP activity

In next experiment, we used a similar CM stored at $-20^{\circ} \mathrm{C}$ for 3 weeks, and also did not reveal a loss of the osteogenic properties (data not shown).

It was shown that the recombinant BMP preparations kept at low temperature $\left(-70^{\circ} \mathrm{C}\right)$ for a short period of time practically did not lose their osteoinduction effectiveness compared to fresh recombinant BMP preparations after short-term storage at $4{ }^{\circ} \mathrm{C}$. Currently in our experiments we successfully use such preparations stored for weeks at $-70^{\circ} \mathrm{C}$ or even at $-20^{\circ} \mathrm{C}$ (data not shown).

BMP2 and BMP7 trigger their signaling pathway via recruiting a minimally heterotetrameric complex, which consists of BMP receptor types I and II with minimally two subunits of each type into a complex [19]. Our experiments, as well as in vitro and in vivo studies of other scientists, demonstrated the best osteoinductive properties of BMP2/7 heterodimers compared with the corresponding homodimers [12]. BMP2 mainly binds to BMPRIA/ALK3 and BMPRIB/ALK6 receptors, while BMP7 selectively binds to ALK2 receptor in a combination with BMPRIB/ALK6 receptors, the best osteoinductive properties of BMP2/7 heterodimer can be caused by combining of ALK3 and ALK2 into a one complex (Fig. 5).

Preparations of the bone morphogenetic protein were generated upon overexpression of optimized versions of expression vectors. Freezing and storage of these preparations for $3 \mathrm{~h}$ do not affect considerably their osteoinductive properties compared with fresh prepared BMP2/7 preparations. Thus, these 
Ta ble 2. The proportions of plasmids expressing BMP2 and BMP7 (fine evaluation)

\begin{tabular}{|l|c|c|c|c|c|c|c|c|}
\hline BMP2, \% & 95 & 85 & 80 & 75 & 70 & 65 & 60 & 55 \\
\hline BMP7, \% & 5 & 15 & 20 & 25 & 30 & 35 & 40 & 45 \\
\hline
\end{tabular}

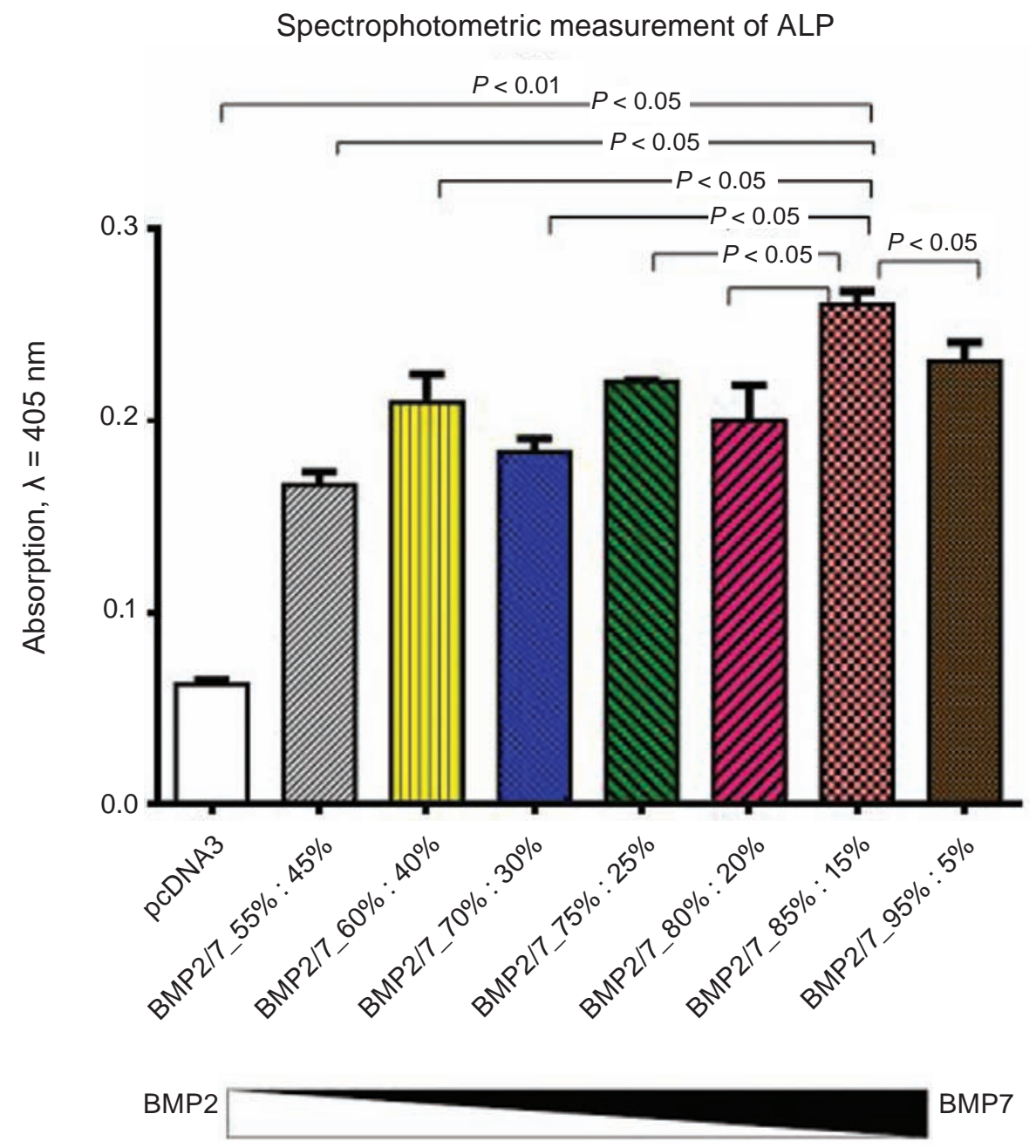

Fig. 3. The BMPs preparation generated upon transfection of $85 \%$ of BMP2 and $15 \%$ of BMP7 plasmids into producer HEK293 cells was the most effective inducer of osteoblast differentiation of C2C12 cells. Producer cells of HEK293 line were transfected with plasmids expressing BMP2 and BMP7 in given ratios. Two days after transfection, the CM with secreted BMP2/7 was collected, and mixed with fresh culture medium. The osteogenic properties of BMPs preparations were tested on $C 2 C 12$ cell line. The intensity of osteogenesis were evaluated spectrophotometricaly by measuring the ALP activity

preparations can be successfully used for generation of highly efficient bone regenerative matrices or in other biological applications.

\section{Acknowlegments}

This research was supported in a part by the Molecular \& Cellular Biotechnologies Grant of the
National Academy of Sciences of Ukraine (Project No 37) and Western-Ukrainian BioMedical Research Center (WUBMRC). Authors are grateful to Dr. Bert Vogelstein for providing pShuttle-CMV plasmid and Dr. Mattew Beckman for providing primary human bone marrow mesenchymal precursor cells. 


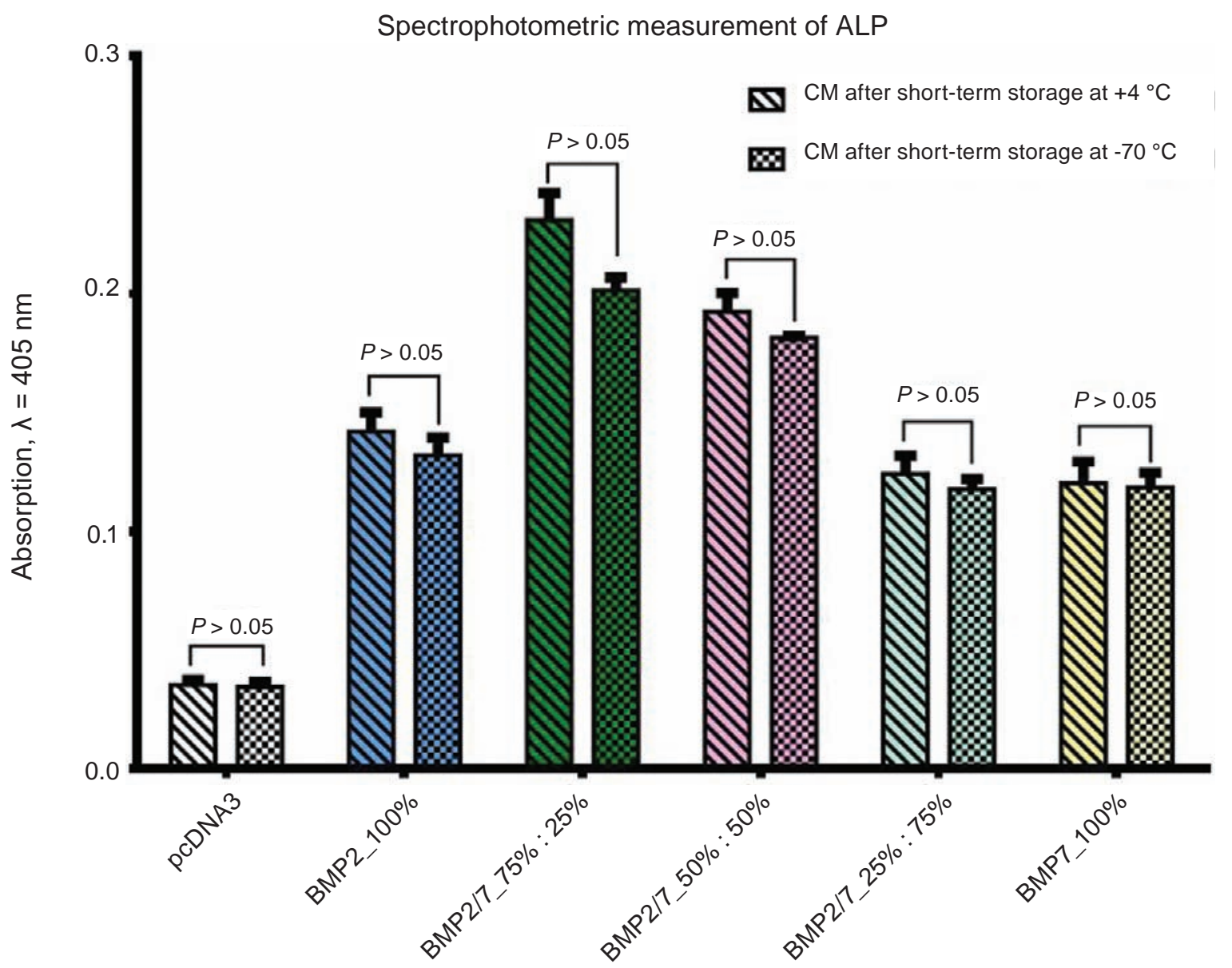

Fig. 4. The freezing-thawing of the BMP2/7 preparations does not reduce their osteoinductive properties. Producer cells of HEK293 line were transfected with plasmids expressing BMP2 and BMP7 in given ratios. Two days after transfection, the CM with secreted BMP2/7 was collected, and divided into two parts (one part was stored at $4{ }^{\circ} \mathrm{C}$ for $3 \mathrm{~h}$ and another one at $-70^{\circ} \mathrm{C}$ during the same period of time). Then CM were mixed with in a $1: 1$ ratio with fresh culture medium. Its osteogenic properties were tested on $\mathrm{C} 2 \mathrm{C} 12$ cell line. The intensity of osteoblast differentiation were evaluated spectrophotometricaly by measuring the ALP activity

\section{Financial support}

The study was supported in a part by the Molecular \& Cellular Biotechnologies Grant of the
National Academy of Sciences of Ukraine (Project No 37) and Western-Ukrainian BioMedical Research Center (WUBMRC). 

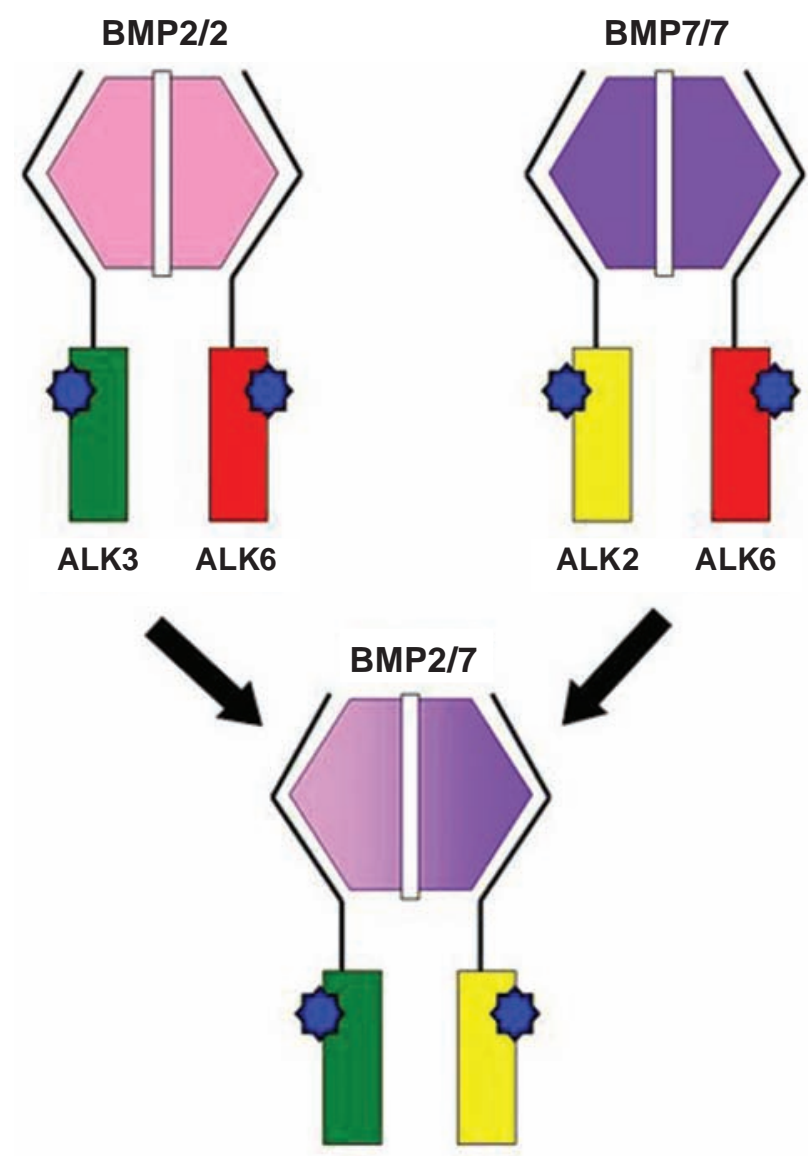

ALK3 ALK2

Fig. 5. Formation and activation of heteromeric BMP type I receptor complex triggered by the BMP2/7 heterodimers

\section{СТВОРЕННЯ ОПТИМІЗОВАНИХ ПРЕПАРАТІВ МОРФОГЕННИХ ПРОТЕЇНІВ КІСТКИ ДЛЯ РЕГЕНЕРАЦІї КІСТКОВОї ТКАНИНИ}

\section{Х. В. Малишева $a^{1,2}$, И. М. Спасюк ${ }^{3}$, О. К. Павленко ${ }^{3}$, Р. С. Стойка ${ }^{1}$, О. Г. Корчинський ${ }^{1,4}$}

${ }^{1}$ Інститут біології клітини НАН України, Львів; ${ }^{2}$ Інститут біології тварин НААН України, Львів;

${ }^{3}$ Львівський національний університет імені Івана Франка, Україна;

${ }^{4}$ Центр інноваційних досліджень в галузі медицини та природничих наук, медичний факультет, Жешувський університет, Польща; e-mail: olexkor@hotmail.com

Корекція спадкових аномалій скелета, травми обширних ділянок кістки, переломи, що тривалий час не загоюються, вимагають ефективного відновлення кісткової ткани- ни. Морфогенні протеїни кістки (МБК) - це сигнальні молекули, які відіграють важливу роль у формуванні та регенерації кісткової і хрящової тканин. Остеоіндуктивні властивості вже існуючих кістковопластичних матеріалів на основі гідроксіапатиту часто бувають непридатними для ефективної регенерації кісткової тканини, i тому зростають вимоги до нових матриксів, що містять МБК для високоефективної локальної регенерації кістки в дефектній ділянці. Метою цього дослідження була оптимізація in vitro остеоіндуктивних властивостей препаратів рекомбінантних МБК, які будуть використані на практиці для регенерації кісткової тканини. Рекомбінантні МБК були продуковані ембріональними клітинами нирок людини (НЕК293) після їх трансфекції або сумісної трансфекції плазмідами, що експресують МБК2 і МБК7 в різних співвідношеннях. Якість препаратів МБК підтверджена їхньою здатністю індукувати in vitro остеобластну 
диференціацію клітин лінії С2C12. Активність лужної фосфатази, що широко використовується як маркер остеобластної диференціації, вимірювали за допомогою спектрофотометра. Виявлено, що найефективнішим індуктором остеобластної диференціації був препарат рекомбінантного МБК, що утворюється за сумісної трансфекції плазмідами МБК2 і МБК7 у співвідношенні 85 до 15\% відповідно. Цей результат, імовірно, пояснюється створенням найсприятливіших умов для формування МБК2/7 гетеродимерів. Під час зберігання заморожених препаратів МБК2/7 протягом 3 годин в ході експериментів або декількох тижнів в ході щоденної роботи вони практично не призводили до втрати їхніх остеоіндуктивних властивостей в порівнянні зі свіжовиділеними препаратами МБК2/7 і тому можуть успішно використовуватися у створенні високоефективних регенеративних кісткових матриксів.

К л юч о в і сл ов а: морфогенні протеїни кістки, регенерація кісткової тканини, остеогенез, мезенхімні стовбурові клітини миші, лужна фосфатаза.

\section{СОЗДАНИЕ}

\section{ОПТИМИЗИРОВАННЫХ}

ПРЕПАРАТОВ МОРФОГЕННЫХ ПРОТЕИНОВ КОСТИ ДЛЯ РЕГЕНЕРАЦИИ КОСТНОЙ ТКАНИ

\section{Х. В. Мальшева ${ }^{1,2}$, И. М. Спасюк, А. К. Павленко ${ }^{3}$, Р. С. Стойка ${ }^{1}$, А. Г. Корчинский ${ }^{1,4}$}

${ }^{1}$ Институт биологии клетки НАН Украины, Львов; ${ }^{2}$ Институт биологии животных НААН Украины, Львов;

$3^{3}$ Львовский национальный университет имени Ивана Франко, Украина;

${ }^{4}$ Центр инновационных исследований в области медицины и естественных наук, медицинский факультет, Жешувский университет, Польша; e-mail: olexkor@hotmail.com

Коррекция наследственных аномалий скелета, длительно незаживающие переломы, травмы, затрагивающие широкие области кости, требуют эффективного восстановления костной ткани. Морфогенные протеины кости (МБК) являются сигнальными молекулами, которые играют решающую роль в формирова- нии и регенерации костной и хрящевой тканей. Остеоиндуктивные свойства существующих костнопластических материалов на основе гидроксиапатита часто непригодны для эффективной регенерации костной ткани, следовательно повышаются требования к новым матриксам, содержащим МБК для высокоэффективной локальной регенерации кости в дефектной области. Целью данного исследования было оптимизирование in vitro остеоиндуктивных свойств препаратов рекомбинантных МБК, которые будут использованы на практике для регенерации костной ткани. Рекомбинантные МБК были продуцированы эмбриональными клетками почек человека (НЕК293) после их трансфекции либо совместной трансфекции плазмидами, экспрессирующими МБК2 и МБК7 в различных соотношениях. Качество препаратов МБК было подтверждено их способностью индуцировать in vitro остеобластную дифференциацию клеток линии С2C12. Активность щелочной фосфатазы, которая широко используется в качестве маркера остеобластной дифференциации, измеряли с помощью спектрофотометра. Установлено, что наиболее эффективным индуктором остеобластной дифференциации был препарат рекомбинантного МБК, образующийся при совместной трансфекции плазмидами МБК2 и МБК7 в соотношении 85 к 15\% соответственно. Данный результат, предположительно, объясняется созданием наиболее благоприятных условий для формирования МБК $2 / 7$ гетеродимеров. При хранении замороженных препаратов МБК2/7 в течении 3 часов в ходе экспериментов, или в течение нескольких недель при ежедневной работе, они практически не теряли своих остеоиндуктивных свойств по сравнению со свежевыделенными препаратами МБК2/7 и поэтому могут быть успешно использованы для производства высокоэффективных регенеративных костных матриксов.

К л юче вы е сл о ва: морфогенные протеины кости, регенерация костной ткани, остеогенез, мезенхимные стволовые клетки мыши, щелочная фосфатаза.

\section{References}

1. Chuva de Sousa Lopes SM, Feijen A, Korving J, Korchynskyi O, Larsson J, Karlsson S, ten Dijke P, Lyons KM, Goldschmeding R, 
Doevendans P, Mummery CL. Connective tissue growth factor expression and Smad signaling during mouse heart development and myocardial infarction. Dev Dyn. 2004; 231(3): 542-550.

2. Urist MR. Bone: formation by autoinduction. Science. 1965; 150(3698): 893-899.

3. Groeneveld EH, Burger EH. Bone morphogenetic proteins in human bone regeneration. Eur $J$ Endocrinol. 2000; 142(1): 9-21.

4. Wang RN, Green J, Wang Z, Deng Y, Qiao M, Peabody M, Zhang Q, Ye J, Yan Z, Denduluri S, Idowu O, Li M, Shen C, Hu A, Haydon RC, Kang R, Mok J, Lee MJ, Luu HL, Shi LL. Bone Morphogenetic Protein (BMP) signaling in development and human diseases. Genes Dis. 2014; 1(1): 87-105.

5. Carreira AC, Alves GG, Zambuzzi WF, Sogayar MC, Granjeiro JM. Bone Morphogenetic Proteins: structure, biological function and therapeutic applications. Arch Biochem Biophys. 2014; 561: 64-73.

6. Harrison CA, Al-Musawi SL, Walton KL. Prodomains regulate the synthesis, extracellular localisation and activity of TGF- $\beta$ superfamily ligands. Growth Factors. 2011; 29(5): 174-186.

7. Heldin CH, Miyazono K, ten Dijke P. TGFbeta signalling from cell membrane to nucleus through SMAD proteins. Nature. 1997; 390(6659): 465-471.

8. de Caestecker M. The transforming growth factor-beta superfamily of receptors. Cytokine Growth Factor Rev. 2004; 15(1): 1-11.

9. Nohe A, Hassel S, Ehrlich M, Neubauer F, Sebald W, Henis YI, Knaus P. The mode of bone morphogenetic protein (BMP) receptor oligomerization determines different BMP-2 signaling pathways. J Biol Chem. 2002; 277(7): 5330-5338.

10. Horbelt D, Denkis A, Knaus P. A portrait of Transforming Growth Factor $\beta$ superfamily signalling: Background matters. Int $J$ Biochem Cell Biol. 2012; 44(3): 469-474.

11. Heldin $\mathrm{CH}$, Moustakas A. Role of Smads in TGF $\beta$ signaling. Cell Tissue Res. 2012; 347(1): 21-36.
12. Aoki H, Fujii M, Imamura T, Yagi K, Takehara K, Kato M, Miyazono K. Synergistic effects of different bone morphogenetic protein type I receptors on alkaline phosphatase induction. J Cell Sci. 2001; 114(Pt 8): 1483-1489.

13. Bragdon B, Moseychuk O, Saldanha S, King D, Julian J, Nohe A. Bone morphogenetic proteins: a critical review. Cell Signal. 2011; 23(4): 609620.

14. Gautschi OP, Frey SP, Zellweger R. Bone morphogenetic proteins in clinical applications. ANZ J Surg. 2007; 77(8): 626-631.

15. Bishop GB, Einhorn TA. Current and future clinical applications of bone morphogenetic proteins in orthopaedic trauma surgery. Int Orthop. 2007; 31(6): 721-727.

16. Korchynskyi O, ten Dijke P. Identification and functional characterization of distinct critically important bone morphogenetic protein-specific response elements in the Id1 promoter. $\mathrm{J}$ Biol Chem. 2002; 277(7): 4883-4891.

17. van der Horst G, van Bezooijen RL, Deckers MM, Hoogendam J, Visser A, Löwik CW, Karperien M. Differentiation of murine preosteoblastic KS483 cells depends on autocrine bone morphogenetic protein signaling during all phases of osteoblast formation. Bone. 2002; 31(6): 661-669.

18. Krause C, Korchynskyi O, de Rooij K, Weidauer SE, de Gorter DJ, van Bezooijen RL, Hatsell S, Economides AN, Mueller TD, Löwik CW, ten Dijke P. Distinct modes of inhibition by sclerostin on bone morphogenetic protein and Wnt signaling pathways. $\mathrm{J} \mathrm{Biol}$ Chem. 2010; 285(53): 41614-41626.

19. Wrana JL, Attisano L, Wieser R, Ventura F, Massagué J. Mechanism of activation of the TGF-beta receptor. Nature. 1994; 370(6488): 341-347.

Received 03.10.2016 